\title{
Bioavailability of lutein/zeaxanthin isomers and macular pigment optical density response to macular carotenoid supplementation: A randomized double blind placebo controlled study
}

\author{
Vijaya Juturu $^{1 *}$, James P Bowman ${ }^{2}$, Nicole T. Stringham ${ }^{3}$ and James M. Stringham ${ }^{4}$ \\ ${ }^{1}$ Omni Active Health Technologies Inc. Morristown NJ 07960, USA \\ ${ }^{2}$ James P Bowman \& Associates LLC, 6409 Roth Ridge Loveland, OH 45140, USA \\ ${ }^{3}$ Interdisciplinary Neuroscience Program, Biomedical Health Sciences Institute, University of Georgia, Athens, GA 30602 USA \\ ${ }^{4}$ Nutritional Neuroscience Laboratory, Department of Physiology and Pharmacology, USA
}

\begin{abstract}
Purpose: To examine the bioavailability of Lutein $(\mathrm{L})$ and Zeaxanthin isomers $(\mathrm{Zi})$ concentrations in serum and changes in MPOD over 12 weeks macular carotenoids supplementation in healthy young subjects.

Methods: In a randomized double blind placebo controlled study, twenty eight $(\mathrm{N}=28)$ healthy young male and female volunteers were randomized to receive one of three doses $(6 \mathrm{mg} \mathrm{L} / 1 \mathrm{mg} \mathrm{Zi,} 10 \mathrm{mg} \mathrm{L} / 2 \mathrm{mg} \mathrm{Zi}$ or $20 \mathrm{mg} \mathrm{L} / 4 \mathrm{mg} \mathrm{Zi}$ ) for 12 weeks. Blood samples for serum L/Zi and macular pigment optical density (MPOD) were determined every two weeks over the 12 week study period. Serum lutein and zeaxanthin isomers concentration was determined by HPLC and MPOD by heterochromatic flicker photometry (HFP). The area under the curve (AUC) was calculated using the linear trapezoidal rule. $\mathrm{C}_{\text {max }}$ and $t_{\text {max }}$ was determined over 12 weeks of supplementation.

Results: No significant difference in serum L/Zi concentrations of each dose group at baseline visit. Serum levels of $\mathrm{L}$ and $\mathrm{Zi}$ increased at 2 weeks, and peaked by 12 weeks. Median serum concentrations of $6 \mathrm{mg} \mathrm{L}, 10 \mathrm{mg} \mathrm{L}$ or $20 \mathrm{mg} \mathrm{L}$ groups from baseline to month 3 increased from 0.323 to $1.984 \mu \mathrm{g} / \mathrm{dL}$ (6-fold increase), from 0.353 to $2.234 \mu \mathrm{g} / \mathrm{dL}$ ( 7 -fold increase), and from 0.372 to 3.163 (10-fold increase), respectively (all $\mathrm{P}<0.001$ ). Median serum concentrations of $1 \mathrm{mg} Z \mathrm{Z}$, 2 $\mathrm{mg} Z \mathrm{Zi}$ or $4 \mathrm{mg} Z \mathrm{Z}$ groups from baseline to month 3 increased from 0.060 to $0.377 \mu \mathrm{g} / \mathrm{dL}$ (6-fold increase), from 0.096 to $0.350 \mu \mathrm{g} / \mathrm{dL}$ (4-fold increase), and from 0.117 to 0.391 (3.3 fold increase), respectively (all $\mathrm{P}<0.001)$. Area under curve (AUC) for serum lutein increased $(\mathrm{p}<0.01)$ and AUC for serum $\mathrm{Zi}$ increased $(\mathrm{p}<0.03$ ) with increased dose of $\mathrm{L} / \mathrm{Zi}$ over placebo. AUCL increased in $6 \mathrm{mg}$ of L \& $1 \mathrm{mg} Z \mathrm{Zi}$ by 6 fold, 8 fold in $10 \mathrm{mgL}$ and $2 \mathrm{mg}$, and 12 fold in $20 \mathrm{mg} \mathrm{L}$ and $4 \mathrm{mg} Z \mathrm{Zi}$ over placebo, respectively. AUCZi increased in all three treatments over placebo by 3 fold, 4 fold and 5 fold, respectively. MPOD increased significantly from baseline to month 3 increased for all $\mathrm{L} / \mathrm{Zi}$ treatments over placebo. No adverse events were observed with any dose of lutein.
\end{abstract}

Conclusion: Increasing doses of macular carotenoid supplementation significantly increased the serum AUC levels of lutein and zeaxanthin isomers, and doses up to $20 \mathrm{mg}$ were safely administered. A long-term large clinical trial is necessary to investigate the safety and efficacy of macular carotenoids in health and disease.

\section{Introduction}

Lutein and zeaxanthin are 2 of the most abundant carotenoids present in the diet, and they are the pigments responsible for the bright colours of many fruits and vegetables. Lutein and zeaxanthin are isomers that differ by site of a single double bond [1,2]. Zeaxanthin exists as 3 stereoisomeric forms; (3R, 3'R)-zeaxanthin and (3R, 3'S)-zeaxanthin (also called meso-zeaxanthin) are the main forms present in the macula of the retina, while small amounts of (3S, 3'S)-zeaxanthin have also been detected [3,4]. Humans are unable to synthesize lutein and zeaxanthin isomers; thus, these nutrients are obtained from natural dietary sources or from supplementation. Circulating and tissue levels of xanthophylls increase with supplementation with lutein/zeaxanthin $[5,6]$. However, variability in their bioavailability has been reported [7-9], and has been related to factors such as the matrix of the formulation (e.g., presence of fat), the form in which they were administered (i.e., free versus esterified) and interactions with other nutrients [10,11]. Supplementation with lutein and zeaxanthin [i.e., (3R,3'R)-zeaxanthin and meso-zeaxanthin] is generally considered to be safe [12].

Epidemiological data indicate that the average intake of lutein and zeaxanthin from dietary sources is in the range of 1 to $2 \mathrm{mg}$ /day (approximately 0.01 to $0.03 \mathrm{mg} / \mathrm{kg}$ body weight/day), corresponding serum concentrations of approximately $0.4 \mu \mathrm{mol} / \mathrm{L}$ have been measured $[10,13,14]$. Supplementation with lutein/zeaxanthin has been shown to increase levels in the blood and tissues where these

Correspondence to: Vijaya Juturu, Ph.D., F.A.C.N. Director (Global) Scientific and Clinical Affairs, OmniActive Health Technologies, 67 East Park Place, Suite 500, Morristown, NJ07950, USA, E-mail: v.juturu@omniactives.com

Key words: lutein, zeaxanthin isomers, bioavailability, area under curve

Received: April 16, 2016; Accepted: May 10, 2016; Published: May 13, 2016 
Juturu V (2016) Bioavailability of lutein/zeaxanthin isomers and macular pigment optical density response to macular carotenoid supplementation: A randomized double blind placebo controlled study

xanthophylls are selectively deposited (such as the macula lutea of the retina) $[15,16]$. However, considerable inter-individual variability in serum concentrations and macular pigment density has been reported following supplementation with lutein/zeaxanthin [17]. Some of the factors that may contribute to this variation include those that affect the absorption of xanthophylls, such as the matrix of the formulation, the form in which they were administered (i.e., free versus esterified). Lutein occurs as a single stereoisomer $\left[\left(3 R, 3^{\prime} R, 6^{\prime} R\right)-\beta, \varepsilon\right.$-carotene- $3,3^{\prime}$ diol] while zeaxanthin occurs as a mixture of stereoisomers, with the 2 most prominent forms in the macula of the retina being $\left(3 R, 3^{\prime} R\right)$ $\beta, \beta$-carotene-3,3'-diol (referred to as zeaxanthin) and (3R,3'S)- $\beta, \beta$ carotene-3,3'-diol (referred to as mesozeaxanthin). The physical and chemical properties of lutein and zeaxanthin isomers are summarized in Figure 1. Most of the studies are single dose studies $[7,18,19]$ and a multiple-dose pharmokinetis (PK) study [20] reported in the literature.The present study was designed to compare, in human subjects, the bioavailability of lutein and zeaxanthin isomers when ingested at different doses compared with placebo and to study the changes in MPOD by macular carotenoid dose over three months supplementation(Figure 2).

\section{Subjects and methods}

Twenty eight (28) volunteers participated in this study recruited from the University of Georgia population in accordance with the IRB guidelines. This study was reviewed and approved by the University of Georgia Institutional Review Board. Informed consent was obtained for each subject, and the study adhered to the tenets of the Declaration of Helsinki.This study is registered at ISRCTN\#54990825. Subjects were randomly assigned to one of four groups: Placebo (Group I, safflower oil, $\mathrm{N}=5$ ), $6 \mathrm{mg} \mathrm{L} / 1$ mg Zi (Group II, $\mathrm{n}=7$ ), $10 \mathrm{mg} \mathrm{L} / 2 \mathrm{mg} \mathrm{Zi} \mathrm{(Group} \mathrm{III,} \mathrm{n}=8$ ), or $20 \mathrm{mg}$ $\mathrm{L} / 4 \mathrm{mg} \mathrm{Zi}$ (Group IV, $\mathrm{n}=8$ ). Identical looking capsules containing only safflower oil was used as a placebo. Lutemax $2020(\mathrm{~L} / \mathrm{Zi})$ at different doses (6 mg L/1mg Zi; $10 \mathrm{mg} \mathrm{L} / 2 \mathrm{mg} \mathrm{Zi}$; $20 \mathrm{mgL} / 4 \mathrm{mg} \mathrm{Zi})$ and placebos supplied by OmniActive Health Technologies Ltd., Mumbai, India. Subjects instructed to take one capsule per day with a meal for 12 weeks but otherwise to follow their normal diet. Compliance was ensured with weekly phone calls and subjects were requested to return bottles to count left over pills in the bottle.

Subjects' anthropometric measurements, health habits and medical history recorded during their screening visit. Normal healthy subjects and no history of smoking included in the study. Subjects with chronic

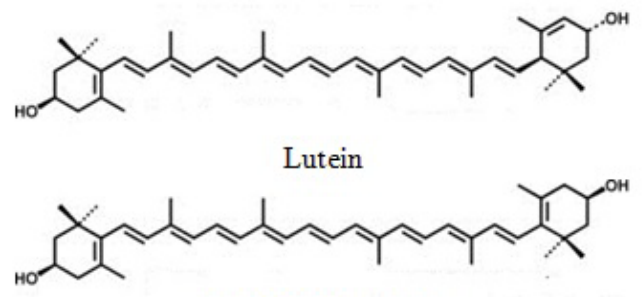

(3R, $\left.3^{\prime} \mathrm{R}\right)$-Zeaxanthin

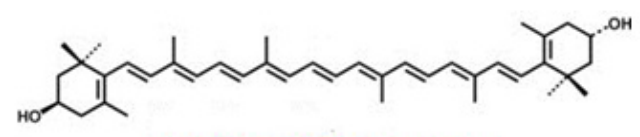

(3R,3'S;meso)-Zeaxanthin

Figure 1. Molecular Structures of Lutein and Zeaxanthin Isomers.
2A. $A \cup C_{L}$

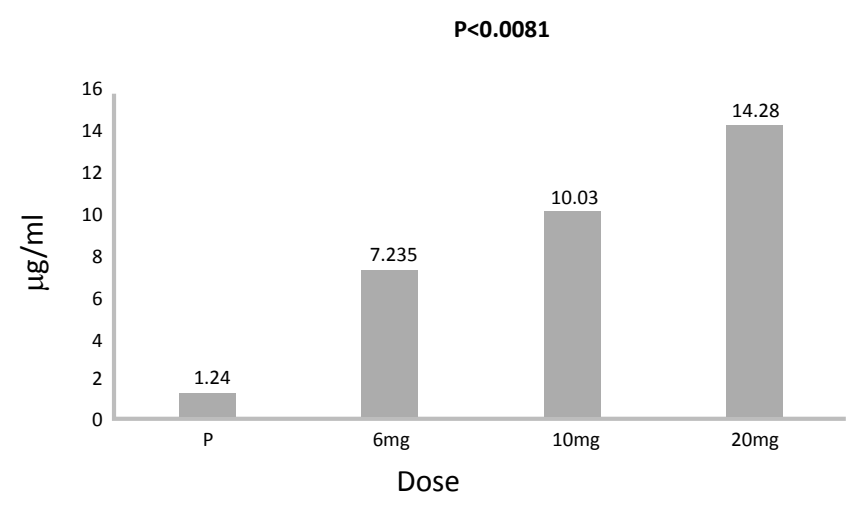

2B. $A \cup C_{z i}$

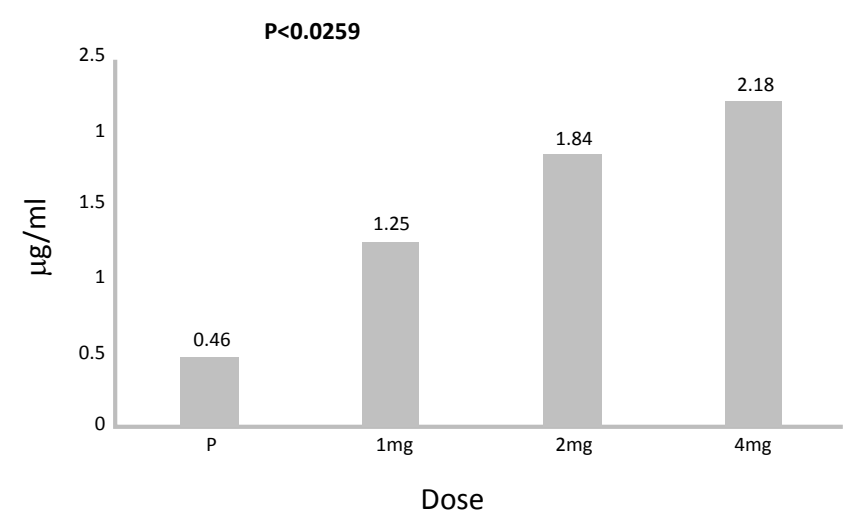

Figure 2. A and 2 B Lutein and zeaxanthin isomers bioavailability measured by AUC ( $\mu \mathrm{g}$ / $\mathrm{mL}$ ) over 12 weeks of supplementation.

conditions excluded such as prescriptions or surgical treatments. Pregnancy and lactating women and subjects with a BMI higher than 27 and took supplements containing any of the carotenoids excluded. Subjects were instructed to keep up their current diet and not to change their diet during the study period. In consideration of MPOD testing, all subjects had uncorrected or contact lens-corrected visual acuity of $20 / 20$ or better in the test (right) eye, and had no current or earlier history of ocular pathology.

Subjects were instructed to visit the laboratory every 2 weeks for blood draws and vision testing. Fasting blood draw samples were collected to assess serum $\mathrm{L} / \mathrm{Zi}$ and Macular pigment measurement was assessed for each subject.

\section{Serum analysis}

Serum concentrations of lutein and zeaxanthin isomers were obtained by HPLC according to a method described in detail [21]. Samples were taken at baseline and every 2 weeks over the 12-week study period.

Detection wavelengths were $\lambda=447 \mathrm{~nm}$ (lutein) and $450 \mathrm{~nm}$ (zeaxanthin isomers).

\section{Measurement of macular pigment optical density (MPOD)}

MPOD in the central retina was assessed with a non-invasive, perceptual task called customized heterochromatic flicker photometry 
Juturu V (2016) Bioavailability of lutein/zeaxanthin isomers and macular pigment optical density response to macular carotenoid supplementation: A randomized double blind placebo controlled study

[22]. A densitometer (Macular Metrics Corp., Rehoboth, MA) described by Wooten et al.[23] was used for this purpose.The densitometer, detailed measurement procedures, and the principle of HFP have been fully described in earlier publications [23].Measurements were taken at baseline and every 2 weeks over the 12 week study period.We obtained spatial profiles of MPOD at each visit, with measures at 10', 20', 30', 1.75 degrees, and 2.75 degrees of retinal eccentricity.

The primary study endpoint was the 12 week area under the curve for plasma lutein (AUC). Secondary endpoints included the maximum concentration $\left(C_{\max }\right)$, the time at which the maximum concentration was observed for plasma lutein $\left(T_{\max }\right)$ and $C_{\max }$, and $T_{\max }$ was also calculated for zeaxanthin. The area under the curve was calculated using the linear trapezoidal rule. In order to meet the assumption of normality, statistics on AUC and $C_{\max }$ were based on log transformed values for individual subjects

\section{Statistical analysis}

Descriptive statistics (mean and standard deviation) were reported. One-way and repeated-measures analysis of variance, curve fitting, and correlational analyses were conducted. All statistical analyses performed with SAS (NC). Tukey-Kramer adjusted $P$ values were used to find where the post hoc differences occurred within statistically significant interaction or main effects, with significance set at $P<0.05$. Multiple models comparing group differences analyzed (raw values at all time points, raw values adjusted for baseline, and change scores). Statistical significance determined at $\mathrm{p}<=0.05$ level.Interaction and main effects were considered statistically significant at $P<0.05$ and trends at $P<0.1$.

\section{Results}

\section{Baseline characteristics}

Table 1 provides baseline characteristics of the study. No significant difference was found in any of the groups.

\section{Lutein bioavailability}

The mean serum plasma and $\mathrm{AUC}_{\mathrm{L}}$ concentrations were significantly higher $(p<0.001)$ compared to placebo. Highly significant difference in $\mathrm{AUC}_{\mathrm{L}}$ was observed between Group I (placebo) and Group IV (20 mg L, $\mathrm{p}<0.001)$ followed by group III $(10 \mathrm{mg} \mathrm{L}, \mathrm{p}<0.019)$ and a trend of significant difference in $\mathrm{AUC}_{\mathrm{L}}$ between Group I (placebo) and Group II $(6 \mathrm{mgL}, \mathrm{p}<0.1)$ was observed. There was a significant difference between Group II (6 mg L and $20 \mathrm{mg}$ ) and Group IV over 12 week period $(\mathrm{p}<0.03)$ (Table 2$)$.

Between treatment analysis of covariance, significant differences were observed between Group I and II (placebo vs. $6 \mathrm{mg} \mathrm{L}, \mathrm{p}<0.0494$ ), Group I and Group III (placebo vs. $10 \mathrm{mg} \mathrm{L}, \mathrm{p}<0.034$ ) and Group I and Group IV (placebo vs. $20 \mathrm{mgL}, \mathrm{p}<0.0002$ ). Significant difference in $\mathrm{C}_{\max }$ was observed between Group I and Group IV $(\mathrm{p}<0.015)$ and Group III and Group IV ( $10 \mathrm{mg} \mathrm{L} v s .20 \mathrm{mg}, \mathrm{p}<0.023$, Table 3 ). The time to reach maximum concentration $\left(T_{\max }\right)$ for lutein was not significantly different for treatments.

\section{Zeaxanthin isomers bioavailability}

Highly significant difference in $\mathrm{AUC}_{\mathrm{Zi}}$ was observed between placebo and Group IV (4 mg Zi, p<0.005) followed by group III (2 $\mathrm{mg} \mathrm{Zi}, \mathrm{p}<0.02)$ and a trend of significant difference in $\mathrm{AUC}_{\mathrm{Zi}}$ between Group I and Group II (placebo and $6 \mathrm{mg} \mathrm{L}, \mathrm{p}<0.1$ ) observed. There was a trend of significant difference between Group I and IV $(6 \mathrm{mg} \mathrm{L}$ and $20 \mathrm{mgL}$ ) over 12 week period $(\mathrm{p}<0.07)$.

Between treatment analysis of covariance, significant difference between Group I and II (placebo vs. $1 \mathrm{mg} \mathrm{Zi,} \mathrm{p<0.0541),} \mathrm{Group} \mathrm{I} \mathrm{and}$ Group III (placebo vs. $2 \mathrm{mg} \mathrm{Zi,} \mathrm{p}<0.0114$ ) and Group I and Group IV (placebo vs. $4 \mathrm{mg} \mathrm{Zi,}<<0.0005$ ) was observed. Significant difference in Cmax was observed between Group I and Group IV ( $<<0.0363$, Table 3 ) and no significance in other groups was observed. The time to reach maximum concentration $\left(T_{\max }\right)$ for $\mathrm{Zi}$ was not significantly different for treatments.

\section{Change in MPOD}

MPOD responses were detected at 4 weeks in Group II and Group III (NS) at the standard, 30' retinal locus followed by a significant change in MPOD in Group II at 12 weeks. A non-significant change in MPOD was observed in Group III and IV at week 6. Significant change in MPOD was observed in Group III and IV at week 8 to week $12(\mathrm{p}<0.001)$. No significant difference between Group III and IV were observed.

\section{Discussion}

In several conducted studies where lutein preparations were repeatedly administered at doses ranging from 4 to $20 \mathrm{mg} /$ day for up to 20 weeks, plasma concentrations of lutein increased by 3 - to 8 -fold compared to controls or baseline, with levels back to baseline by 3 to 4 weeks following cessation of treatment $[9,24-26])$. This is our first

Table 1. Baseline characteristics.

\begin{tabular}{|c|c|c|c|c|}
\hline Variables & Group I, Placebo & Group II, 6 mgL/1 mg Zi & $\begin{array}{l}\text { Group III, } \\
10 \text { mg L/2 mg Zi }\end{array}$ & $\begin{array}{c}\text { Group IV, } \\
20 \mathrm{mg} \mathrm{L} / 4 \mathrm{mg} \mathrm{Zi}\end{array}$ \\
\hline Age,y & $21.4 \pm 2.07$ & $20.0 \pm 1.195$ & $20.63 \pm 0.92$ & $21.56 \pm 3.20$ \\
\hline BMI, $\mathrm{kg} / \mathrm{m}^{2}$ & $26.2 \pm 1.5$ & $19.7 \pm 0.50$ & $21.54 \pm 2.63$ & $21.53 \pm 3.33$ \\
\hline Males/Females & $3 \mathrm{M} / 2 \mathrm{~F}$ & $3 \mathrm{M} / 5 \mathrm{~F}$ & $3 \mathrm{M} / 5 \mathrm{~F}$ & $3 \mathrm{M} / 5 \mathrm{~F}$ \\
\hline Smokers & None & None & None & None \\
\hline
\end{tabular}

Table 2. MPOD (OD Units) Response by Week and Dose (Mean \pm SD).

\begin{tabular}{|l|c|c|c|c|c|c|c|}
\hline \multicolumn{1}{|c|}{} & Baseline & Week 2 & Week 4 & Week 6 & Week 8 & Week 10 & Week 12 \\
\hline Group I, Placebo & $0.44 \pm 0.29$ & $0.45 \pm 0.27$ & $0.48 \pm 0.33$ & $0.48 \pm 0.34$ & $0.54 \pm 0.40$ & $0.49 \pm 0.33$ & $0.47 \pm 0.29$ \\
\hline Group II, $6 \mathrm{mgL} / 1 \mathrm{mg} \mathrm{Zi}$ & $0.73 \pm 0.15$ & $0.75 \pm 0.11$ & $0.75 \pm 0.12$ & $0.79 \pm 0.10$ & $0.81 \pm 0.13$ & $0.82 \pm 0.14$ \\
\hline Group III, $10 \mathrm{mgL} / 2 \mathrm{mg} \mathrm{Zi}$ & $0.42 \pm 0.25$ & $0.45 \pm 0.24$ & $0.49 \pm 0.26$ & $0.51 \pm 0.29$ & $0.54 \pm 0.33$ & $0.54 \pm 0.31$ & $0.56 \pm 0.11$ \\
\hline Group IV, $20 \mathrm{mgL} / 4 \mathrm{mg} \mathrm{Zi}$ & $0.43 \pm 0.15$ & $0.45 \pm 0.15$ & $0.48 \pm 0.16$ & $0.48 \pm 0.18$ & $0.50 \pm 0.19$ & $0.57 \pm 0.17$ & $0.55 \pm 0.17$ \\
\hline
\end{tabular}

MPOD: Macular Pigment Optical Density; OD: Optical Density 
Juturu V (2016) Bioavailability of lutein/zeaxanthin isomers and macular pigment optical density response to macular carotenoid supplementation: A randomized double blind placebo controlled study

Table 3. Maximum Concentrations $\left(\mathrm{C}_{\mathrm{Max}}\right)$ for $\mathrm{L}$ and $\mathrm{Zi}$ in different groups (Mean $\left.\pm \mathrm{SD}\right)$.

\begin{tabular}{|l|c|c|}
\hline Groups & $\begin{array}{c}\text { BL (Before } \\
\text { supplementation) }\end{array}$ & After Supplementation \\
\cline { 2 - 3 } & C $_{\text {max }}$ & C $_{\text {max }}$ \\
\hline \multicolumn{2}{|c|}{ Serum Lutein, $\mu \mathrm{g} / \mathrm{mL}$ (Mean $\pm \mathrm{SD})$} \\
\hline Group I, Placebo & $0.343 \pm 0.154$ & $0.539 \pm 0.113$ \\
\hline Group II, $6 \mathrm{mgL} / 1 \mathrm{mg} \mathrm{Zi}$ & $0.359 \pm 0.281$ & $2.353 \pm 0.609$ \\
\hline Group III, $10 \mathrm{mgL} / 2 \mathrm{mg} \mathrm{Zi}$ & $0.388 \pm 0.177$ & $2.509 \pm 0.634$ \\
\hline Group IV, $20 \mathrm{mgL} / 4 \mathrm{mg} \mathrm{Zi}$ & $0.817 \pm 1.379$ & $4.374 \pm 2.774$ \\
\hline \multicolumn{3}{|c|}{ Serum Zi, $\mu \mathrm{g} / \mathrm{mL}(\mathrm{Mean} \pm \mathrm{SD})$} \\
\hline Group I, Placebo & $0.141 \pm 0.062$ & $0.189 \pm 0.056$ \\
\hline Group II, $6 \mathrm{mgL} / 1 \mathrm{mg} \mathrm{Zi}$ & $0.087 \pm 0.064$ & $0.406 \pm 0.078$ \\
\hline Group III, $10 \mathrm{mgL} / 2 \mathrm{mg} \mathrm{Zi}$ & $0.101 \pm 0.026$ & $0.482 \pm 0.132$ \\
\hline Group IV, $20 \mathrm{mgL} / 4 \mathrm{mg} \mathrm{Zi}$ & $0.193 \pm 0.212$ & $0.614 \pm 0.318$ \\
\hline
\end{tabular}

BL: Baseline; $\mathrm{C}_{\mathrm{Max}}$ : Maximum concentration; L: Lutein; Zi: Zeaxanthin isomers

attempt to study the concentrations of $\mathrm{L} / \mathrm{Zi}$ in serum at different doses for a period of 12 weeks to see consistent increase of serum levels of macular carotenoids and MPOD response for each dose. L/Zi capsules are a concentrate containing at least $80 \%$ carotenoids, with a minimum of $63.75 \%$ lutein and $11.25 \%$ zeaxanthin isomers in the free form. (3R,3'R)- zeaxanthin and (3R,3'S)-zeaxanthin (i.e.,meso-zeaxanthin) are present at a ratio of approximately 50:50, and batch analytical data suggest the ratio of these 2 isomers may vary between 40:60 to 60:40. In general, the ratio of lutein to zeaxanthin in natural dietary sources is about 5:1 [27].

In a study where volunteers (4/sex/group) were administered capsules containing crystalline lutein ( 4 to $20 \mathrm{mg}$ ) plus zeaxanthin ( 0.34 to $1.7 \mathrm{mg}$ ) for 42 days and monitored further for 25 days, steady state concentrations of lutein and zeaxanthin were reached between days 38 to 43 , and the elimination half-life was determined to be 5 to 7 days for both compounds [28]. In this study, greater the dose of $\mathrm{L} / \mathrm{Zi}$ greater the response in serum macular carotenoids. Increase in serum levels of $\mathrm{L}$ and $\mathrm{Zi}$ are consistent with the dose. At week 12 the higher dose appears to plateau. These results suggest the macular carotenoids are being taken up by the tissues. Hence we saw significance in change in MPOD at 12 weeks in all doses. These results suggest the presence of a striking treatment effect where relative to placebo, greater Lutein and Zeaxanthin isomer bioavailability was observed in one or more of the active treatments.Because these differences were observed at a statistically significant level in a study of modest sample size, the strength of the treatment effect and the potential clinical importance of these findings are underscored. Further studies are required to explore further in a large population.

The pharmacokinetics of lutein in humans was assessed in two studies utilising $\left[{ }^{14} \mathrm{C}\right]$ and $\left[{ }^{13} \mathrm{C}\right]$ labelled lutein from spinach and kale, respectively $[29,30]$. The ${ }^{14} \mathrm{C}$-lutein concentrations reached its peak $\left(\mathrm{C}_{\max }\right)$ of $2.08 \%$ of dose/L at 14 hours after administration with a calculated half-life of approximately 10 days [29].The primary route of elimination was through faeces, which accounted for $45 \%$ of the eliminated lutein, whereas, $10 \%$ of the lutein was eliminated in the urine within the first 2 days. In the study by Novotny et al.[30], the mean AUC over 28 days was calculated to be $42.8 \mu \mathrm{M} \times \mathrm{h}$, with the $\mathrm{C}_{\max }$ containing $3.6 \%$ of the administered dose. This study attempted to see the changes of AUC L/Zi over 12 weeks. Maximum concentrations $\left(\mathrm{C}_{\max }\right)$ were determined based on the concentrations of $\mathrm{L}$ and $\mathrm{Zi}$ from individual data sets(Table 3). Ocular tissues, particularly the retina, selectively retain high concentrations of lutein and zeaxanthin [31,32]. The levels of these xanthophylls are up to 1,000-fold higher than in other tissues, and other carotenoids are only present in trace amounts
$[31,32]$. In studies where lutein (extracted from marigold petals) administered as either the free or esterified form for durations ranging from 12 to 42 weeks, an accumulation of lutein in the macula was observed, as demonstrated by the increase in macular pigment density [33-35]. Carotenoids have also been found in variable amounts in other tissues in humans, including the kidneys, buccal mucosal cells, adrenal glands, adipose tissue and liver [6,36].

Several clinical trials have compared bioavailability of free lutein/ zeaxanthinversus their esterified forms, though the results from these studies been mixed. Norkus et al. [37] reported bioavailability of free lutein greater than esterified lutein.Seventy-two healthy volunteers administered capsules containing free lutein $(12.2 \mathrm{mg})$ or lutein esters (equivalent to $13.5 \mathrm{mg}$ freelutein) for 28 days. The test articles formulated as beadlets in identical hard-shell capsules, and administered with a standard breakfast cereal and an $8 \mathrm{oz}$. serving of $2 \%$ cow milk.Subjects administered the formulation containing free lutein had significantly greater changes in serum lutein levels, and a significantly higher AUC (by 17\%), compared to those consuming esterified lutein.In addition, regression modelling indicated that the form of lutein (i.e., free versusesterified) remains a significant contributing factor to the serum lutein response, even after controlling for factors including age, gender, body mass index, and serum lipids.In this study, AUC increased as the dose increased over placebo. $\mathrm{AUC}_{\mathrm{L}}$ increased 6 folds higher in Group II over placebo (Group I), 8 folds higher Group III and 12 folds higher in Group III over placebo (all $P<0.01$ ). AUC $\mathrm{Zin}_{\mathrm{i}}$ increased by 3,4 and 5 folds inGroup II, III and IV over Group I (all $P<0.05$ ). The difference is due to differential spatial accumulation of lutein relative to zeaxanthin may be relevant to retinal health.

Conversely, no significant differences in serum lutein levels were reported following supplementation with free lutein $(6.0 \mathrm{mg})$ or esterified lutein (5.5 $\mathrm{mg}$ of free lutein) for 9 days in a cross-over study with 10 healthy males [11]. In this study, both formulations were provided as crystalline suspensions in oil in soft gel capsules and administered with a test meal. In another cross-over study, subjects administered a single dose of a formulation containing unesterified lutein or lutein diesters $(0.5$ and $0.67 \mu \mathrm{mol}$ lutein $/ \mathrm{kg}$ body weight in 10 and 8 subjects, respectively), along with a test meal [38]. Supplementation with lutein diesters produced a significantly higher maximum serum concentration of lutein and a higher mean AUC (by $61.6 \%)$, compared to supplementation with free lutein.It should be noted, though, that different formulations were used for the test articles, with free lutein administered as a crystalline oil suspension in soft gel capsules, whereas esterified lutein was administered as a powder in hard gel capsules.As such, the interpretation of these findings is unclear as they may have been confounded by differences in formulation dissolution.In the current study, median serum concentrations of6 $\mathrm{L}$, $10 \mathrm{mg} \mathrm{L}$ or $20 \mathrm{mg} \mathrm{L}$ groups from baseline to month 3 increased from 0.323 to $1.984 \mu \mathrm{g} / \mathrm{dL}$ (6-fold increase), from 0.353 to $2.234 \mu \mathrm{g} / \mathrm{dL}$ (7fold increase), and from 0.372 to3.163 (10-fold increase), respectively (all $P<0.001$ ). Median serum concentrations of $1 \mathrm{mg} \mathrm{Zi}, 2 \mathrm{mg} \mathrm{Zi}$ or $4 \mathrm{mg}$ $\mathrm{Zi}$ groups from baseline to month 3 increased from 0.060 to $0.377 \mu \mathrm{g} /$ $\mathrm{dL}$ (6-fold increase), from 0.096 to $0.350 \mu \mathrm{g} / \mathrm{dL}$ (4-fold increase), and from 0.117 to 0.391 (3.3 fold increase), respectively (all $P<0.001$ ).

The bioavailability of esterified versus free zeaxanthin has also been evaluated in 1 study where a single dose of esterified or free $3 \mathrm{R}, 3^{\prime} \mathrm{R}$-zeaxanthin $(5 \mathrm{mg})$ was administered to 12 healthy volunteers in a cross-over study design [39]. Both test articles were suspended in sunflower oil and mixed with a yogurt which was consumed along with a standardized breakfast. Supplementation with $3 \mathrm{R}, 3^{\prime}$ R-zeaxanthin 
Juturu V (2016) Bioavailability of lutein/zeaxanthin isomers and macular pigment optical density response to macular carotenoid supplementation: A randomized double blind placebo controlled study

palmitate (esterified) produced approximately 2-fold higher AUC values compared to supplementation with free $3 \mathrm{R}, 3^{\prime} \mathrm{R}$-zeaxanthin $(\mathrm{p}<0.05)$. Supplementation with L/Zi (free) had higher AUC values and very quick response and MPOD also detectable at 4 weeks but significance observed at 8 to 12 weeks.

The role of lutein and zeaxanthin in eye health has been further supported by some epidemiological studies reporting an inverse relationship between lutein/zeaxanthin intake and eye disease, particularly AMD and cataracts [16,40-44]. Several controlled intervention studies have also indicated that macular pigment density or dietary supplementation with lutein improves parameters of visual function, such as visual acuity $[45,46]$, glare recovery, and contrast sensitivity $[26,45,47-49]$. A number of clinical studies have evaluated the pharmacokinetic properties of lutein and zeaxanthin.Overall, an increased intake of lutein and zeaxanthin, either through natural dietary sources or supplementation, produces corresponding increases in levels of these carotenoids in systemic circulation.

\section{Acknowledgements}

We wish to thank the volunteers who participated in this study for their willingness and diligence in complying with the protocol. The study was sponsored by OmniActive Health Technologies Ltd, India.

\section{Conflict of interest}

VJ is an employee of OmniActive Health Technologies.

\section{References}

1. Bone RA, Landrum JT, Friedes LM, Gomez CM, Kilburn MD, et al. (1997) Distribution of lutein and zeaxanthin stereoisomers in the human retina. Exp Eye Res 64: 211-218. [Crossref]

2. Schenk ER, Mendez V, Landrum JT, Ridgeway ME, Park MA, et al. (2014) Direct Observation of Differences of Carotenoid Polyene Chain cis/trans Isomers resulting from Structural Topology. Anal Chem 86: 2019-2024. [Crossref]

3. Bone RA, Landrum JT (1992) Distribution of macular pigment components, zeaxanthin and lutein, in human retina. Methods Enzymol 213: 360-366. [Crossref]

4. Bone RA, Landrum JT, Hime GW, Cains A, Zamor J (1993) Stereochemistry of the human macular carotenoids. Invest Ophthalmol Vis Sci 34: 2033-2040. [Crossref]

5. Abdel-Aal el-SM, Akhtar H, Zaheer K, Ali R (2013) Dietary sources of lutein and zeaxanthin carotenoids and their role in eye health. Nutrients 5: 1169-1185. [Crossref]

6. Johnson EJ, Hammond BR, Yeum KJ, Qin J, Wang XD, et al. (2000) Relation among serum and tissue concentrations of lutein and zeaxanthin and macular pigment density. Am J Clin Nutr 71: 1555-1562. [Crossref]

7. Kostic D, White WS, Olson JA (1995) Intestinal absorption, serum clearance, and interactions between lutein and beta-carotene when administered to human adults in separate or combined oral doses. Am J Clin Nutr 62: 604-610. [Crossref]

8. Burri BJ, Neidlinger TR (2000) Range of serum carotenoid concentrations induced by feeding carotenoid supplements. Faseb J 14: A234.

9. Torbergsen AC, Collins AR (2000) Recovery of human lymphocytes from oxidative DNA damage; the apparent enhancement of DNA repair by carotenoids is probably simply an antioxidant effect. Eur J Nutr 39: 80-85. [Crossref]

10. IOM. ß-Carotene and other carotenoids. In: Dietary Reference Intakes for Vitamin C, Vitamin E, Selenium, and Carotenoids. Panel on Dietary Antioxidants and Related Compounds, Subcommittees on Upper Reference Levels of Nutrients and Interpretation and Uses of DRIs, Standing Committee on the Scientific Evaluation of Dietary Reference Intakes, Food and Nutrition Board, Institute of Medicine (IOM). Washington (DC): National Academy Press (NAP), 2000; pp. 325-382. Available at: $\mathrm{http}: / /$ www.nap.edu/openbook.php?record_id=9810\&page $=325$.

11. Chung HY, Rasmussen HM, Johnson EJ (2004) Lutein bioavailability is higher from lutein-enriched eggs than from supplements and spinach in men. $J$ Nutr 134: 18871893. [Crossref]

12. JECFA. Lutein from Tagetes erecta L. In: Safety Evaluation of Certain Food Additives.
Sixty-third Meeting of the Joint FAO/WHO Expert Committee on Food Additives, June 8 17, 2004, Geneva, Switz. (WHO Food Additives Series, no 54). Geneva, Switz.: World Health Organization (WHO), International Programme on Chemical Safety (IPCS), 2006; pp. 49-86, 637-638. Available at: http://whqlibdoc.who.int/ publications/2006/9241660546_eng.pdf.

13. EFSA. EFSA Panel on Food Additives and Nutrient Sources added to Food (ANS); Scientific Opinion on the reevaluation of lutein (E 161b) as a food additive on request of the European Commission (question no EFSA-Q-2008-787, adopted on 7 July 2010 by European Food Safety Authority). EFSA J 2010; 8:1678.

14. Shao A, Hathcock JN (2006) Risk assessment for the carotenoids lutein and lycopene. Regul Toxicol Pharmacol 45: 289-298. [Crossref]

15. Whitehead AJ, Mares JA, Danis RP (2006) Macular pigment: a review of current knowledge. Arch Ophthalmol 124: 1038-1045. [Crossref]

16. Connolly EE, Beatty S, Loughman J, Howard AN, Louw MS, et al. (2011) Supplementation with all three macular carotenoids: response, stability, and safety. Invest Ophthalmol Vis Sci 52: 9207-9217. [Crossref]

17. Norkus EP, Norkus KL, Dharmarajan TS, Schierle J, Schalch W (2010) Serum lutein response is greater from free lutein than from esterified lutein during 4 weeks of supplementation in healthy adults. $J$ Am Coll Nutr 29: 575-585. [Crossref]

18. Bowen PE, Herbst-Espinosa SM, Hussain EA, Stacewicz-Sapuntzakis M (2002) Esterification does not impair lutein bioavailability in humans. J Nutr 132: 3668-3673. [Crossref]

19. Thürmann PA, Schalch W, Aebischer JC, Tenter U, Cohn W (2005) Plasma kinetics of lutein, zeaxanthin, and 3-dehydro-lutein after multiple oral doses of a lutein supplement. Am J Clin Nutr 82: 88-97. [Crossref]

20. Stringham JM, Stringham NT (2016) Serum and retinal responses to three different doses of macular carotenoids over 12 weeks of supplementation. Exp Eye Res (In press).

21. Stringham JM, Hammond BR, Nolan JM, Wooten BR, Mammen A, et al. (2008) The utility of using customized heterochromatic flicker photometry (cHFP) to measure macular pigment in patients with age-related macular degeneration. Exp Eye Res 87: 445-453. [Crossref]

22. Wooten BR, Hammond BR, and Smollon B (2005) Assessment of the validity of heterochromatic flicker photometry for measuring macular pigment optical density in normal subjects. Optom Vis Sci 82: 378-386.

23. Khachik F, Beecher GR, Smith JC Jr (1995).Lutein, lycopene, and their oxidative metabolites in chemoprevention of cancer. J Cell Biochem 22: 236-246.

24. Schalch W, Cohn W, Aebischer C-P (2001) Pilot Study on the Dose Response to Lutein Formulated as Beadlets in Capsules: Plasma Kinetics and Accumulation in the Macula After Oral Lutein Administration Under Defined Dietary Conditions in Humans. (2001; Unpublished report No. 1003951). From Basle, Switz.: F. Hoffmann-La Roche Ltd. Cited In: JECFA, 2006

25. Olmedilla B, Granado F, Southon S, Wright AJ, Blanco I, et al. (2002) A European multicentre, placebo-controlled supplementation study with alpha-tocopherol, carotene-rich palm oil, lutein or lycopene: analysis of serum responses. Clin Sci (Lond) 102: 447-456. [Crossref]

26. Thurnham DI (2007) Macular zeaxanthins and lutein -- a review of dietary sources and bioavailability and some relationships with macular pigment optical density and agerelated macular disease. Nutr Res Rev 20: 163-179. [Crossref]

27. Cohn W, Schalch W, Aebischer CP. Pilot study on the dose response to lutein formulated as beadlets in capsules: plasma kinetics and accumulation in the macula after oral lutein administration under defined dietary conditions in humans. 2001 (Unpublished report No. 1005367) from Basle, Switz.: F. Hoffmann-La Roche Ltd. Cited In: JECFA, 2006.

28. de Moura FF, Ho CC, Getachew G, Hickenbottom S, Clifford AJ (2005) Kinetics of 14C distribution after tracer dose of 14C-lutein in an adult woman. Lipids 40: 10691073. [Crossref]

29. Novotny JA, Kurilich AC, Britz SJ, Clevidence BA (2005) Plasma appearance of labeled beta-carotene, lutein, and retinol in humans after consumption of isotopically labeled kale. J Lipid Res 46: 1896-1903. [Crossref]

30. Whitehead AJ, Mares JA, Danis RP (2006) Macular pigment: a review of current knowledge. Arch Ophthalmol 124: 1038-1045. [Crossref]

31. Handelman GJ, Dratz EA, Reay CC, van Kuijk JG (1988) Carotenoids in the human macula and whole retina. Invest Ophthalmol Vis Sci 29: 850-855. [Crossref]

32. Landrum JT, Bone RA, Joa H, Kilburn MD, Moore LL, et al. (1997) A one year study 
Juturu V (2016) Bioavailability of lutein/zeaxanthin isomers and macular pigment optical density response to macular carotenoid supplementation: A randomized double blind placebo controlled study

of the macular pigment: the effect of 140 days of a lutein supplement. Exp Eye Res 65: 57-62. [Crossref]

33. Berendschot TTJM, Goldbohm RA, Klopping WAA, van de Kraats J, van Norel J, et al. (2000) Influence of lutein supplementation on macular pigment, assessed with two objective techniques. Invest Ophthalmol Vis Sci 41: 3322-3326. [Crossref]

34. Duncan JL, Aleman TS, Gardner LM, De Castro E, Marks DA, et al. (2002) Macular pigment and lutein supplementation in choroideremia. Exp Eye Res 74: 371-381. [Crossref]

35. Furr HC, Clark RM (1997) Intestinal absorption and tissue distribution of carotenoids. J Nutr Biochem 8: 364-377

36. Norkus EP, Norkus KL, Dharmarajan TS, Schierle J, Schalch W (2010) Serum lutein response is greater from free lutein than from esterified lutein during 4 weeks of supplementation in healthy adults. $J$ Am Coll Nutr 29: 575-585. [Crossref]

37. Bowen PE, Herbst-Espinosa SM, Hussain EA, Stacewicz-Sapuntzakis M (2002) Esterification does not impair lutein bioavailability in humans. $J$ Nutr 132: 3668-3673. [Crossref]

38. Breithaupt DE, Weller P, Wolters M, Hahn A (2004) Comparison of plasma responses in human subjects after the ingestion of $3 R, 3 R^{\prime}$-zeaxanthin dipalmitate from wolfberry (Lycium barbarum) and non-esterified 3R,3R'-zeaxanthin using chiral highperformance liquid chromatography. Br J Nutr 91: 707-713. [Crossref]

39. Seddon JM, Ajani UA, Sperduto RD, Hiller R, Blair N, et al. (1994) Dietary carotenoids, vitamins $\mathrm{A}, \mathrm{C}$ and $\mathrm{E}$ and advanced age-related macular degeneration. JAMA 272: 14131420. [Crossref]

40. Ma L, Dou HL, Wu YQ, Huang YM, Huang YB, et al. (2012) Lutein and zeaxanthin intake and the risk of age-related macular degeneration: a systematic review and metaanalysis. Br J Nutr 107: 350-359. [Crossref]
41. Alves-Rodrigues A, Shao A (2004) The science behind lutein. Toxicol Lett 150: 57-83. [Crossref]

42. Ribaya-Mercado JD, Blumberg JB (2004) Lutein and zeaxanthin and their potential roles in disease prevention. J Am Coll Nutr 23: 567S-587S. [Crossref]

43. Barker FM 2nd (2010) Dietary supplementation: effects on visual performance and occurrence of AMD and cataracts. Curr Med Res Opin 26: 2011-2023. [Crossref]

44. Wong IY, Koo SC, Chan CW (2011) Prevention of age-related macular degeneration. Int Ophthalmol 31: 73-82. [Crossref]

45. Richer S, Stiles W, Statkute L, Pulido J, Frankowski J, et al. (2004) “Double-masked, placebo-controlled, randomized trial of lutein and antioxidant supplementation in the intervention of atrophic age-related macular degeneration: the Veterans LAST study (Lutein Antioxidant Supplementation Trial),". Optometry 75: 216-230. [Crossref]

46. van der Made SM, Kelly ER, Kijlstra A, Plat J, Berendschot TT (2016) Increased Macular Pigment Optical Density and Visual Acuity following Consumption of a Buttermilk Drink Containing Lutein-Enriched Egg Yolks: A Randomized, DoubleBlind, Placebo-Controlled Trial. J Ophthalmol: 9035745

47. Massacesi AL, Faletra R, Gerosa F, Staurenghi G, Orzalesi N (2001) The effect of oral supplementation of macular carotenoids (lutein and zeaxanthin) on the prevention of agerelated macular degeneration: a 18 months of follow up study. Invest Ophthalmol Vis Sci 42: S234.

48. Stringham JM, Hammond BR Jr (2005) Dietary lutein and zeaxanthin: possible effects on visual function. Nutr Rev 63: 59-64. [Crossref]

49. Lien EL, Hammond BR (2011) Nutritional influences on visual development and function. Prog Retin Eye Res 30: 188-203. [Crossref]

Copyright: (92016 Juturu V. This is an open-access article distributed under the terms of the Creative Commons Attribution License, which permits unrestricted use, distribution, and reproduction in any medium, provided the original author and source are credited. 